\title{
PENGARUH KEMAMPUAN MEMBACA, PENGUASAAN KOSAKATA, DAN PEMAHAMAN TATA BAHASA TERHADAP KEMAMPUAN MENULIS NARASI SISWA
}

\author{
A. Andriyani Asra dan Haryadi \\ Linguistik Terapan, Universitas Negeri Yogyakarta \\ nani_asra@yahoo.co.id.prof_haryadi@yahoo.co.id
}

\begin{abstract}
ABSTRAK
Penelitian ini bertujuan untuk mengetahui pengaruh (1) kemampuan membaca, penguasaan kosakata, dan pemahaman tata bahasa secara bersama-sama; (2) kemampuan membaca; (3) penguasaan kosakata; (4) pemahaman tata bahasa terhadap kemampuan menulis narasi siswa SMP Negeri di Kabupaten Bulukumba. Jenis penelitian ini adalah ex-post facto, dengan melibatkan tiga variabel bebas dan satu variabel terikat. Populasi penelitian adalah seluruh siswa SMP Negeri di Kabupaten Bulukumba yang telah menerapkan Kurikulum 2013. Teknik penentuan sampel yang digunakan adalah proportional random sampling. Instrumen penelitian adalah satu angket dan tiga tes. Data dianalisis dengan teknik statistik Regresi Ganda yang diteruskan dengan Regresi Parsial. Hasil penelitian sebagai berikut. (1) Kemampuan membaca, penguasaan kosakata, dan pemahaman tata bahasa secara bersama-sama berpengaruh terhadap kemampuan menulis narasi siswa $\left(\mathrm{F}_{\text {hitung }}=24,475 ;(0,000<0,05)\right.$. (2) Kemampuan membaca berpengaruh terhadap kemampuan menulis narasi siswa $\left(\mathrm{t}_{\text {hitung }}=4,481 ; 0,000<0,05\right)$. (3) Penguasaan kosakata berpengaruh terhadap kemampuan menulis narasi siswa $\left(t_{\text {hitung }}=3.022 ; 0,003<\right.$ 0,05). (4) Pemahaman tata bahasa tidak berpengaruh terhadap kemampuan menulis narasi siswa $\left(\mathrm{t}_{\text {hitung }}=1,113 ; 0,267>0,05\right)$.
\end{abstract}

Kata Kunci: kemampuan membaca, penguasaan kosakata, pemahaman tata bahasa, kemampuan menulis narasi

\section{THE INFLUENCE OF READING ABILITY, VOCABULARY MASTERY, AND GRAMMATICAL COMPREHENSION TOWARDS THE STUDENTS' NARRATION WRITING ABILITY}

\begin{abstract}
This research aims to find out(1) the simultaneous influence of reading ability, vocabulary mastery, and grammatical comprehension to the narration writing ability of state junior high school students in Bulukumba Regency; and the influence of (2) reading ability; (3) vocabulary mastery; (4) grammatical comprehension to the students' narration writing ability. This research is ex-post facto, involving three independent variables and one dependent variable. The population of the research is the students of state junior high schools in Bulukumba Regency, which have implemented 2013 curriculum. Proportional random sampling was applliedin this research. The instruments of the research are 1 questionnaire and three tests. Data analysis was performed by applying statistic techniques of multiple regression and partial regression. The results show that (1) reading ability, vocabulary mastery, and grammatical comprehension are simultaneously influencial towards the students' narration writing abilty $\left(\mathrm{F}_{\text {hitung }}=24,475 ;(0,000<0,05)\right.$.(2) Reading ability influences the students' narration writing abilty $\left(\mathrm{t}_{\text {hitung }}=4,481 ; 0,000<0,05\right)$.(3) Vocabulary mastery influences the students' narration writing abilty $\left(\mathrm{t}_{\text {hitung }}=3.022 ; 0,003\right.$ $<0,05)$.(4) Grammatical comprehension does not influence the students' narration writing $\operatorname{abilty}\left(\mathrm{t}_{\text {hitung }}=1,113 ; 0,267>0,05\right)$.
\end{abstract}

Keywords: reading ability, vocabulary mastery, grammatical comprehension, narration writing ability. 


\section{PENDAHULUAN}

Menulis secara umum boleh dikatakan kegiatan yang sulit. Di samping dituntut kemampuan berpikir yang memadai, kegiatan menulis juga melibatkan berbagai keterampilan dan pengetahuan yang harus dikuasai terlebih dahulu. Siswa yang akan menulis harus menguasai permasalahan yang akan ditulisnya. Selain itu, siswa juga dituntut mampu mengemukakan gagasan dengan baik dan benar.

Pembelajaran menulis dalam Kurikulum 2013 tidak sekadar mengarahkan siswa untuk menuangkan gagasan, ide, atau informasi dengan kalimat yang benar secara gramatikal saja, tetapi harus mengemasnya dalam bentuk teks. Oleh sebab itu, kurikulum ini menerapkan pendekatan berbasis teks. Pendekatan ini memaparkan bermacam-macam teks dengan perbedaan pada tujuan dan pengemasannya. Dalam penerapannya, siswa didorong untuk mengembangkan pengetahuan mereka dalam memahami dan menulis berbagai jenis teks.

Salah satu jenis tulisan yang harus dikuasai siswa adalah narasi. Heffernan \& Lincoln (1990:110) mengungkapkan "narration is writing about a succession of events. The simplest kind of narration follows chronological order: the order in which the narrated events actually occurred or could have occurred". Pernyataan tersebut menunjukkan bahwa narasi merupakan sebuah tulisan mengenai rangkaian peristiwa. Jenis paling sederhana dari narasi mengikuti urutan kronologis di mana urutan peristiwa diceritakan seperti hal yang benar-benar terjadi.

Rangkaian peristiwa dalam narasi dapat dikembangkan berdasarkan urutan tempat, waktu, dan adegan. Cerita yang dikembangkan berdasarkan urutan tempat akan mengisahkan adanya pergantian dari satu tempat ke tempat yang lain. Cerita yang dikembangkan berdasarkan urutan waktu akan mengisahkan adanya pergantian dari waktu ke waktu. Di samping itu, cerita yang menyangkut urutan pengisahan adengan akan mengisahkan perubahan dari satu adegan ke adegan berikutnya. (Suparno \& Yunus, 2007:47)

Dalam pembelajaran menulis narasi, siswa dituntut mampu menulis rangkaian cerita, baik berisi fakta maupun rekaan (Alwasilah \& Alwasilah, 2007:119). Artinya, cerita yang dibuat siswa dapat bersumber dari pengalaman pribadi, pengalaman orang lain, atau pun fantasi yang dirangkai menjadi sebuah cerita yang utuh. Tulisan narasi dapat diwujudkan ke dalam beberapa tipe teks, misalnya cerita fabel, cerita pendek, cerita biografi.

Ada beberapa unsur yang harus diperhatikan dalam mengembangkan sebuah narasi, antara lain: unsur orientasi, komplikasi, evaluasi, resolusi, dan koda. Akan tetapi, Sinar (2008:72) mengungkapkan bahwa unsur evaluasi dan koda bukan elemen wajib yang harus selalu hadir dalam sebuah teks narasi. Evaluasi dan koda dapat disampaikan secara tersirat dalam sebuah karangan narasi.

Siahaan \& Shinoda (2008:73) mengungkapkan bahwa orientasi merupakan bagian awal cerita. Bagian ini dapat berisi pengenalan tokoh, dan latar yang digunakan dalam cerita, baik latar waktu, tempat, maupun sosial.

Komplikasi merupakan bagian inti teks narasi. Bagian ini berisi masalah yang dialami tokoh utama dalam cerita. Zainurrahman (2011: 41) mengungkapkan bahwa rangkaian masalah dalam bagian ini disebut evaluasi. Evaluasi bertujuan memberikan alasan mengenai konflik yang terjadi dalam cerita. Biasanya, evaluasi berisi gambaran perasaan tokoh mengenai masalah. Lebih dari itu, evaluasi menjadi dasar penyelesaian masalah.

Tahap terakhir adalah resolusi. Resolusi merupakan bagian akhir cerita yang berisi suatu pemecahan masalah atau penyelesaian suatu masalah sehingga masalah-masalah yang terjadi pada tahap komplikasi diselesaikan pada bagian ini. Selain resolusi, koda juga merupakan bagian akhir dari sebuah narasi. Namun, Zainurrahman (2011:42) mengungkapkan bahwa koda bersifat opsional, terkadang disampaikan secara tersurat dalam bacaan, dan kadang pula secara tersirat.

Kenyataan di lapangan menunjukkan bahwa kemampuan menulis narasi siswa SMP di Kabupaten Bulukumba belum sesuai dengan yang diharapkan. Terkadang siswa mampu menyampaikan cerita secara lisan, tetapi tidak mampu menuliskannya. Hal ini didukung dengan budaya bercerita yang turun-temurung dari nenek moyang sehingga kebiasaan ini menjadi sebuah pola yang tidak dapat terhindarkan. Karena itu, jika siswa diminta untuk menulis 
cerita, mereka lebih cenderung menulis dengan bahasa lisan.

Selain kebiasaan bercerita yang masih kuat, penyebab belum tercapainya tujuan pembelajaran menulis narasidi antaranya, sebagian siswa lebih mampu menggambarkan sesuatu secara rinci, namun tidak dapat menghadirkan alur cerita. Selain itu, siswa juga cenderung mengalami kesulitan dalam menghadirkan konflik. Beragamnya kemampuan menulis narasi siswa dalam penelitian ini menjadi permasalahan yang perlu diketahui solusinya.

Masalah-masalah tersebut dapat diatasi salah satunya dengan cara melakukan persiapan menulis yang baik. Terdapat banyak cara untuk melakukan persiapan menulis, di antaranya adalah meningkatkan pemahaman terhadap teks yang akan ditulis. Pemahaman merupakan faktor penting dalam menulis teks. Pemahaman akan mendorong siswa untuk memilih isi teks dan bahasa yang tepat agar sesuai dengan jenis tulisan yang akan dibuat. Pemahaman dapat diperoleh melalui kegiatan membaca. Dengan banyak membaca, pemahaman siswa akan semakin bertambah.

Banyak membaca teks narasi dapat menjadi persiapan yang penting sebelum menulis narasi. Johnson (2008:7) menyatakan bahwa kegiatan membaca dapat membantu siswa menjadi penulis yang baik. Dengan banyak membaca teks narasi, siswa dapat mengetahui gaya bercerita pengarang. Selain itu, di dalam teks narasi tersedia ide-ide, kosakata, dan polapola kalimat yang dibutuhkan dalam menulis cerita sehingga dengan memahaminya, siswa akan lebih mudah dalam menuliskannya.

Kenyataan di lapangan menunjukkan bahwa, persiapan semacam ini kurang mendapat dukungan. Bahan bacaan yang tersedia diperpustakaan SMP-SMP di Kabupaten Bulukumba masih kurang bervariasi. Kebanyakkan bahan bacaan yang tersedia berupa buku paket dan koran. Sementara majalah, kumpulan cerpen, puisi, dan novel kurang tersedia. Kurangnya bahan bacaan yang sejenis dengan teks narasi ini diduga menjadi penyebab bervarisinya masalah menulis narasi siswa.

Persiapan menulis yang lain adalah memperkaya kosakata. Ini penting pula untuk persiapan menulis narasi. James \& John (1990:
3) mengungkapkan bahwa dalam menulis, seseorang menyampaikan sesuatu dengan menggunakan kata-kata dan tanda baca. Sebagai contoh, Dalam kegiatan menulis ada tiga proses yaitu: perencanaan, menulis, dan meninjau kembali. Dalam setiap proses ini, penulis merencanakan dan menulis kata-kata yang tepat untuk menyampaikan makna tertentu, dan kemudian meninjau bahan tertulis untuk memastikan bahwa kata-kata yang digunakan efektif untuk mengkomunikasikan ide yang dimaksud.

Tarigan (2008:2) mengungkapkan bahwa kualitas menulis seseorang bergantung pada kuantitas dan kualitas kosakata yang dimilikinya. Ini berarti semakin banyak kosakata berkualitas yang dimiliki siswa maka semakin besar kemungkinannya untuk menghasilkan tulisan yang baik. Pemilihan kata sangat penting dalam mengungkapkan makna tulisan. Karena itu, siswa harus berusaha menyampaikan ceritanya dalam bahasa yang mudah dimengerti. Dengan cara ini, komunikasi dua arah dapat terjalin.

Kosakata dapat diperoleh melalui kegiatan belajar mengajar. Pembelajaran terintegrasi kosakata dengan menulis, akan memudahkan siswa dalam memahami cara pemilihan kata yang sesuai dengan jenis tulisan. Sayangnya, pembelajaran terintegrasi antara kosakata dan menulis masih jarang diterapkan oleh guru di kabupaten Bulukumba. Kebanyakan guru memisahkan pembelajaran kosakata dengan menulis. Akibatnya, kosakata yang dipelajari siswa kurang memberi kontribusi terhadap tulisannya.

Di samping itu, kosakata juga dapat diperoleh melalui media massa di antaranya, televisi, radio, internet, koran, majalah dan lain-lain. Melalui media massa ini secara tidak langsung kosakata siswa dapat bertambah meskipun tidak diajarkan. Akan tetapi, kosakata yang dikuasai siswa cenderung berupa kata-kata modern.

Selain penguasaan kosakata, kegiatan menulis juga tidak terlepas dari pengetahuan tata bahasa dan mekanik. Menurut Browne, (2001:37) tata bahasa merupakan cara pengaturan bahasa, termasuk urutan penempatan kata-kata dalam kalimat sehingga mudah dipahami oleh pengguna bahasa. Srinugraheni \& 
Suyadi (2011:27) berpendapat bahwa tulisan yang baik ditentukan oleh sistematika tulisan yang digunakan. Suatu tulisan akan bermakna dan menarik manakala menggunakan susunan kalimat yang baik. Kata-kata harus disusun menjadi kalimat yang gramatikal dan paragraf yang padu. Selain itu, cerita harus ditulis dengan menggunakan ejaan dan tanda baca yang tepat agar pemaknaannya tidak ambigu. Dengan demikian, pengetahuan tata bahasa dan mekanik juga menjadi persiapan penting bagi siswa untuk menulis narasi.

Hasil wawancara dengan guru memberi informasi bahwa siswa sering kali membuat kesalahan-kesalahan dalam menulis, di antaranya kesalahan dalam menggunakan tanda baca. Siswa sering kali bingung dalam menempatkan tanda koma dan tanda titik. Siswa juga sering salah dalam menggunakan huruf kapital, baik dalam penulisan nama gelar, kota, dan kata ganti. Kesalahan penulisan kata juga sering dilakukan siswa di antaranya, penulisan kata depan dan imbuhan, penulisan kata penghubung, serta penulisan pemenggalan kata. Kesalahan lain yang juga sering diperbuat siswa adalah kesalahan dalam menyusun paragraf.

Selain itu, penulis juga memperoleh informasi dari beberapa orang siswa. Beberapa siswa mengungkapkan bahwa kesalahan-kesalahan yang mereka lakukan disebabkan oleh kurangnya pemahaman terhadap kaidah-kaidah penulisan. Siswa beranggapan bahwa kesalahan penulisan huruf kapital, penulisan kata dan penggunaan tanda baca bukanlah hal yang fatal selama mereka masih memahami makna dari kalimat yang ditulisnya.

Berdasarkan fenomena-fenomena yang diungkapkan sebelumnya, dapat disimpulkan bahwa menulis narasi bukan hal yang mudah untuk dipraktikkan bagi siswa di sekolah menengah pertama, karena banyak faktor yang mempengaruhi kemampuan mereka. Akan tetapi, tidak menutup kemungkinan bagi para siswa untuk memperbaiki kelemahan dalam menulis, yaitu dengan meningkatkan kemampuan membaca, memperkaya kosakata dan tata bahasa, serta bantuan dari guru untuk memperbaiki kesalahan mereka terkait dengan fenomenafenomena yang telah disebutkan sebelumnya.
Secara rinci rumusan masalah dalam penelitian ini (1) bagaimana pengaruh kemampuan membaca, penguasaan kosakata, dan pemahaman tata bahasa secara bersama-sama terhadap keterampilan menulis narasi siswa kelas VII SMP Negeri di Kabupaten Bulukumba?; (2) Bagaimana pengaruh kemampuan membaca terhadap keterampilan menulis narasi siswa kelas VII SMP Negeri di Kabupaten Bulukumba?; (3) Bagaimana pengaruh penguasaan kosakata terhadap keterampilan menulis narasi siswa kelas VII SMP Negeri di Kabupaten Bulukumba?; (4) Bagaimana pengaruh pemahaman tata bahasa terhadap keterampilan menulis narasi siswa kelas VII SMP Negeri di Kabupaten Bulukumba?

Sesuai dengan rumusan masalah, tujuan penelitian ini sebagai berikut. Pertama, mengetahui pengaruh kemampuan membaca, penguasaan kosakata, dan pemahaman tata bahasa secara bersama-sama terhadap keterampilan menulis narasi siswa kelas VII SMP Negeri di Kabupaten Bulukumba. Kedua, mengetahui pengaruh kemampuan membaca terhadap keterampilan menulis narasi siswa kelas VII SMP Negeri di Kabupaten Bulukumba. Ketiga, mengetahui pengaruh penguasaan kosakata terhadap keterampilan menulis narasi siswa kelas VII SMP Negeri di Kabupaten Bulukumba. Keempat, mengetahui pengaruh pemahaman tata bahasa terhadap keterampilan menulis narasi siswa kelas VII SMP Negeri di Kabupaten Bulukumba.

Penelitian ini diharapkan dapat memberikan manfaat baik secara praktis maupun teoretis. Secara teoritis, hasil penelitian ini merupakan salah satu informasi awal yang dapat digunakan sebagai dasar kajian pengembangan keilmuan tentang pentingnya pemahaman bacaan dan penguasaan aspek kebahasaan terhadap kemampuan menulis siswa.

Secara praktis hasil penelitian ini diharapkan sebagai berikut. Pertama, membantu siswa untuk mengembangkan pemahaman tentang pentingnya kemampuan membaca, penguasaan kosakata, dan pemahaman tata bahasa terhadap kemampuan menulis narasi siswa. Kedua, Guru dapat menjadikan hasil penelitian ini sebagai bahan pemikiran dalam rangka meningkatkan kualitas pelaksanaan pembelajaran menulis narasi dengan memperhatikan aspek 
kebahasaan dan non kebahasaan. Ketiga, pihak sekolah dapat menjadikan hasil penelitian ini sebagai bahan pengembangan proses pembelajaran bahasa Indonesia siswa, khususnya kompetensi menulis. Keempat, peneliti lain dapat menjadikan hasil penelitian ini sebagai acuan atau bahan pertimbangan untuk penelitian lebih lanjut jika berminat melakukan penelitian serupa.

\section{METODE}

Penelitian ini adalah penelitian kuantitatif. Metode yang digunakan dalam penelitian adalah ex-post facto. Penelitian ini dilaksanakan di SMP Negeri yang ada di Kabupaten Bulukumba, yaitu SMP Negeri 7 Bulukumba, SMP Negeri 10 Bulukumba, SMP Negeri 25 Bulukumba, dan SMP Negeri 40 Bulukumba. Penelitian ini dilaksanakan Maret 2014 s.d April 2014.

Populasi dalam penelitian ini adalah seluruh siswa SMP Negeri kelas VII tahun ajaran 2013/2014 di Kabupaten Bulukumba yang telah menerapkan Kurikulum 2013. Teknik pengambilan sampel yang digunakan adalah proportional random sampling. Penentuan jumlah sampel dengan teknik ini berdasarkan hasil random kelompok individu sebagaimana yang diungkapkan Arifin (2012:222) bahwa lebih baik mengambil sampel sebesar 25\% dari jumlah sekolah daripada seluruh peserta didik harus didaftar. Berdasarkan pendapat tersebut, maka jumlah sampel dalam penelitian ini adalah $25 \%$ dari 24 kelas yaitu 6 kelas. Jadi sampel penelitian adalah seluruh siswa dari keenam kelas tersebut yaitu 164 orang.

Penelitian ini melibatkan tiga variabel bebas dan satu variabel terikat. Dalam penelitian ini, yang pertama diuji adalah pengaruh ketiga variabel bebas terhadap variabel terikat secara bersama-sama. Setelah itu, pengaruh masingmasing variabel bebas terhadap variabel terikat dengan dikontrol oleh variabel bebas lainnya.

Penelitian ini menggunakan dua istrumen pengumpulan data yaitu rubrik penilaian menulis narasi dan tes pilihan ganda. Rubrik penilaian menulis narasi digunakan untuk memperoleh data variabel terikat. Rubrik penilaian ini mencakup 7 aspek, yaitu: tema, judul, isi, organisasi, struktur kalimat, kosakata, dan mekanik. Tes pilihan ganda digunakan untuk memperoleh data variabel bebas, yaitu kemampuan membaca, penguasaan kosakata, dan pemahaman tata bahasa. Tes pilihan ganda untuk variabel kemampuan membaca mencakup 7 indikator, yaitu: ide-ide penjelas, memprediksi, penilaian, dan pemecahan masalah. Tes pilihan ganda untuk variabel penguasaan kosakata mencakup 8 indikator, yaitu jenis kata, makna kata, sinonim, antonim, homonim, dan peri-bahasa. Tes pilihan ganda untuk variabel pemahaman tata bahasa mencakup 4 aspek, yaitu: fonologi, morfologi, sintaksis, dan semantik.

Ada dua langkah pokok yang harus dilakukan untuk menganalisis data penelitian ini, yaitu (1) uji persyaratan analisis, dan (2) analisis data. Uji persyaratan analisis meliputi uji normalitas data, uji linearitas, uji multikolonearitas, dan uji heteroskedastisitas. Uji persyaratan analisis menggunakan bantuan SPSS version 16.0.

Analisis data meliputi analisis deskriptif, analisis regresi ganda, dan analisis regresi parsial. Analisis data menggunakan bantuan SPSS version 16.0. Analisis deskriptif bertujuan untuk medeskripsikan data masing-masing variabel. meliputi: nilai minimal, nilai maksimal, mean, simpangan baku.

Analisis regresi ganda digunakan untuk menguji hipotesis pertama. Analisis ini bertujuan untuk melihat pengaruh variabel-variabel bebas (X) secara bersamaan terhadap variabel terikat (Y). Dasar pengambilan keputusan yaitu hipotesis diterima jika nilai sig dari regresi ganda $<$ 0,05 . Analisis regresi parsial digunakan untuk menguji hipotesis kedua, ketiga, dan keempat. Analaisis ini dilakukan jika hasil dari analisis regresi ganda adalah signifikan. Regresi parsial bertujuan untuk melihat pengaruh satu variabel bebas terhadap variabel terikat sedangkan variabel bebas lainnya bersifat tetap. Ketentuan yang digunakan yaitu hipotesis diterima jika nilai sig dari regresi parsial $<0,05$.

\section{HASIL DAN PEMBAHASAN}

Hasil penelitian ini meliputi deskripsi data masing-masing variabel dan hasil pengujian hipotesis. Uraian hasil penelitian sebagai berikut. 


\section{Deskripsi Kemampuan Membaca Siswa}

Hasil tes 22 butir soal kemampuan membaca terhadap 164 siswa diperoleh skor tertinggi 20 dan skor terendah 6 . Skor ratarata kemampuan membaca siswa sebesar 14,13 danbesarnya simpangan baku 3,69. Distribusi frekuensi untuk variabel kemampuan membaca selengkapnya disajikan dalam Tabel 1 berikut.

Tabel 1. Distribusi Frekuensi Kemampuan Membaca

\begin{tabular}{ccc}
\hline Interval Skor & Frekuensi & $\begin{array}{c}\text { Persentasi } \\
(\%)\end{array}$ \\
\hline $20-21$ & 6 & 7,32 \\
$18-19$ & 28 & 17,07 \\
$16-17$ & 35 & 21,34 \\
$14-15$ & 32 & 19,51 \\
$12-13$ & 23 & 14,07 \\
$10-11$ & 18 & 10,98 \\
$8-9$ & 10 & 6,09 \\
$6-7$ & 12 & 7.32 \\
Jumlah & 164 & 100 \\
\hline
\end{tabular}

Berdasarkan Tabel 1, dapat diketahui bahwa skor kemampuan membaca siswa terbanyak pada interval $16-17$, yaitu 35 siswa atau $(21,34 \%)$, sebaliknya sebaran skor paling sedikit pada interval 20-21 yaitu 6 siswa $(7,32 \%)$. Dengan demikian dapat disimpulkan bahwa kemampuan membaca siswa cenderung pada skor $16-17$.

\section{Deskripsi Penguasaan Kosakata Siswa}

Hasil tes 14 soal penguasaan kosakata terhadap 164 siswa diperoleh skor tertinggi 10, dan skor terendah 2. Skor rata-rata penguasaan kosakata siswa sebesar 5,83 dan besarnya simpangan baku 2,36. Distribusi frekuensi untuk variabel penguasaan kosakata selengkapnya disajikan dalam Tabel 2.

Berdasarkan Tabel 2, dapat diketahui bahwa skor penguasaan kosakata yang paling banyak dicapai siswa adalah 6 , dengan jumlah siswa 29 orang atau $17,68 \%$, sedangkan yang paling sedikit adalah skor sepuluh dengan jumlah siswa 9 orang atau $6,10 \%$. Dengan demikian, dapat disimpulkan bahwa penguasaan kosakata siswa cenderung pada skor 6 .
Tabel 2. Distribusi Frekuensi Penguasaan Kosakata

\begin{tabular}{ccc}
\hline Skor & Frekuensi & $\begin{array}{c}\text { Persentasi } \\
(\mathbf{\%})\end{array}$ \\
\hline 10 & 9 & 6.10 \\
9 & 17 & 10.37 \\
8 & 21 & 12.20 \\
7 & 16 & 10.98 \\
6 & 29 & 17.68 \\
5 & 24 & 13.41 \\
4 & 13 & 8.54 \\
3 & 17 & 10.37 \\
2 & 18 & 10.98 \\
Jumlah & 164 & 100 \\
\hline
\end{tabular}

Deskripsi Pemahaman Tata Bahasa Siswa

Hasil tes 20 soal pemahaman tata bahasa terhadap 164 siswa diperoleh skor tertinggi 14, dan skor terendah 3. Rata-rata pemahaman tata bahasa siswa sebesar 8,37 dan besarnya simpangan baku 3,08. Distribusi frekuensi untuk variabel pemahaman tata bahasa dapat dilihat pada Tabel 3 berikut.

Tabel 3. Distribusi Frekuensi Pemahaman Tata Bahasa

\begin{tabular}{ccc}
\hline Skor & Frekuensi & $\begin{array}{c}\text { Persentasi } \\
(\%)\end{array}$ \\
\hline 14 & 9 & 5,49 \\
13 & 10 & 6,09 \\
12 & 10 & 6,09 \\
11 & 13 & 10,83 \\
10 & 16 & 9,76 \\
9 & 23 & 14,02 \\
8 & 17 & 10,37 \\
7 & 21 & 12,80 \\
6 & 14 & 8,54 \\
5 & 8 & 4,88 \\
4 & 10 & 6,09 \\
3 & 13 & 10,83 \\
jumlah & 164 & 100 \\
\hline
\end{tabular}

Berdasarkan Tabel 3, dapat dipahami bahwa pemahaman tata bahasa siswa terbanyak pada skor 9 dengan jumlah siswa 23 atau $14,02 \%$, dan paling sedikit pada skor 5 , dengan jumlah siswa 8 atau 4,88\%. Dengan demikian, dapat disimpulkan bahwa pemahaman tata bahasa siswa cenderung pada skor 9 . 
Deskripsi Kemampuan Menulis Narasi Siswa

Berdasarkan hasil analisis data, skor tertinggi kemampuan menulis narasi siswa adalah 57 dan skor terendah adalah 28. Skor rata-rata kemampuan menulis narasi siswa adalah 43,02 dengan simpangan baku 6,12. Adapun distribusi frekuensi untuk variabel kemampuan menulis narasi dapat dilihat pada Tabel 4 berikut.

Tabel 4. Distribusi Frekuensi Pemahaman Tata Bahasa

\begin{tabular}{ccc}
\hline Interval Skor & Frekuensi & $\begin{array}{c}\text { Persentasi } \\
(\%)\end{array}$ \\
\hline $56-59$ & 4 & 2,44 \\
$52-55$ & 12 & 7,32 \\
$48-51$ & 17 & 10,37 \\
$44-47$ & 43 & 26,22 \\
$40-43$ & 46 & 28,05 \\
$36-39$ & 26 & 15,85 \\
$32-35$ & 10 & 8,06 \\
$28-31$ & 6 & 3,66 \\
Jumlah & 164 & 100 \\
\hline
\end{tabular}

Berdasarkan Tabel 4, terlihat bahwa siswa yang memperoleh skor kemampuan menulis narasi terbanyak berada pada interval 40-43 dengan jumlah siswa 46 orang atau $28,05 \%$, dan yang paling sedikit berada pada interval 56 - 59 dengan jumlah siswa 4 orang atau $2,44 \%$. Dengan demikian, dapat disimpulkan bahwa kemampuan menulis narasi siswa cenderung dalam interval skor 40-43.

Salah satu syarat untuk melakukan analisis data dengan regresi adalah terpenuhinya uji persyaratan analisis, yaitu uji normalitas, uji linearitas, uji multikolonearitas, dan uji heteroskedastisitas. Hasil uji persyaratan analisis sebagai berikut.

Hasil uji normalitas data menunjukkan nilai signifikansi variabel kemampuan membaca sebesar 0,068. Variabel penguasaan kosakata nilai signifikansinya sebesar 0,055 . Variabel kompetensi pemahaman tata bahasa nilai signifikansinya sebesar 0,071 . Hasil menulis narasi nilai signifikannya 0,134 . Dengan demikian, dapat disimpulkan bahwa semua variabel populasinya berdistribusi normal karena nilai signifikansinya lebih besar dari 0,05 .
Hasil uji linearitas variabel variabel kemampuan membaca, penguasaan kosakata, pemahaman tata bahasa terhadap kemampuan menulis narasi secara berturut-turut adalah $0,059,0,528,0,183$. nilai (sig) lebih besar dari 0,05 . Dengan demikian dapat disimpulkan bahwa variabel-variabel tersebut linier.

Hasil uji multikolonearitas diperoleh nilai VIF , 1,$490 ; 1,367 ; 1,709$, dan nilai tolerance $0,671,0,731,0,585$. Melalui hasil tersebut dapat diketahui bahwa nilai VIF dari semua variabel kurang dari 10 dan nilai tolerance dari semua variabel bebas lebih besar dari 0,1. Dengan demikian dapat disimpulkan bahwa dalam model regresi tidak terjadi gejala multikolinearitas di antara variabel bebas.

Uji heteroskedastisitas diperoleh hasil bahwa korelasi spearman's rho $\mathrm{X}_{1}$ dengan absolut 0,492 , korelasi spearman's rho $\mathrm{X}_{2}$ dengan absolut adalah 0,066, korelasi spearman's rho $\mathrm{X}_{3}$ dengan nilai absolut adalah 0,850 . Dengan demikian dapat disimpulkan bahwa masalah heteroskedas-tisitas tidak terjadi karena semua nilai korelasi spearman's rho lebih besar dari $\alpha(0,05)$.

Berdasarkan hasil uji persyaratan analisis, dapat disimpulkan bahwa seluruh syarat terpenuhi. Oleh sebab itu, analisis data menggunakan regresi dapat dilakukan.

\section{Pembahasan Hipotesis Pertama}

Hipotesis pertama yaitu "ada pengaruh signifikan kemampuan membaca, penguasaan kosakata, dan pemahaman tata bahasa secara bersama-sama terhadap kemampuan menulis narasi siswa". Hipotesis ini dianalisis dengan mengggunakan uji regresi ganda. Hasil analisis regresi ganda menunjukkan bahwa hipotesis ini diterima. Hal ini ditunjukkan oleh nilai signifikansi $0,000<0,05$. Kontribusi bersama ketiga variabel bebas sebesar 0,315 atau $31,5 \%$. Hal ini berarti bahwa ketiga variabel bebas tersebut memberikan pengaruh sebesar $31,5 \%$ atau dapat menjelaskan varian kemampuan menulis sebesar $31,5 \%$ sisanya dijelaskan oleh variabel lain. Rangkuman hasil perhitungan uji regresi ganda dapat dilihat pada Tabel 5 berikut. 
Tabel 5. Rangkuman Hasil Analisis Regresi Ganda

Model Summaryb

\begin{tabular}{ccccc}
\hline Model & $\mathrm{R}$ & $\begin{array}{c}\mathrm{R} \\
\text { Square }\end{array}$ & $\begin{array}{c}\text { Adjusted R } \\
\text { Square }\end{array}$ & $\begin{array}{c}\text { Std. Error of } \\
\text { the Estimate }\end{array}$ \\
\hline 1 & $.561^{\mathrm{a}}$ & .315 & .302 & 5.11781 \\
\hline
\end{tabular}

a. Predictors: (Constant), X3, X2,X1

b. Dependent

Variable: Y

ANOVA $^{\text {b }}$

\begin{tabular}{lccccc}
\hline Model & $\begin{array}{c}\text { Sum of } \\
\text { Squares }\end{array}$ & df & $\begin{array}{c}\text { Mean } \\
\text { Square }\end{array}$ & F & Sig. \\
\hline 1 Regression & 1923.181 & 3 & 641.060 & 24.475 & $.000^{\mathrm{a}}$ \\
Residual & 4190.722 & 160 & 26.192 & \\
Total & 6113.902 & 163 & & \\
\hline
\end{tabular}

Hasil uji signifikansi pada tabel ANOVA menunjukkan nilai $F_{\text {hitung }}$ sebesar 24,475 pada taraf signifikansi 0,000 . Jika dibandingkan dengan $\alpha 0,05$, nilai signifikansi lebih kecil, atau sig $<0,05$. Besarnya pengaruh variabel $X_{1}, X_{2}$, dan $\mathrm{X}_{3}$ terhadap variabel $\mathrm{Y}$ dapat diketahui dengan melihat nilai $R$ Square pada Tabel Model Summary ${ }^{\mathrm{b}}$. Hasilnya menunjukkan bahwa nilai $R$ Square adalah 0,315 atau 31,5\%. Nilai ini menunjukkan bahwa pengaruh variabel bebas secara bersama-sama terhadap variabel terikat sebesar 31,5\%, dan selebihnya dipengaruhi oleh variabel lain. Adapun pengaruh variabel lain adalah $(100 \%-31,5 \%) 68,5 \%$.

Berdasarkan hasil analisis regresi ganda diperoleh persamaan garis regresi sebagai berikut.

$\hat{Y}=a+b_{1} X_{1}+b_{2} X_{2}+b_{3} X_{3}$ maka

$\hat{Y}=29,560+0,593 X_{1}+0,600 X_{2}+0,189 X_{3}$ $=22,826$

Dimana:

$0,593 \times 22=13,046$

$0,600 \times 10=6$

$0,189 \times 20=3,78$

Konstanta 29,560 menunjukkan bahwa kemampuan menulis narasi siswa sebesar 29,560 jika tidak dipengaruhi oleh kemampuan membaca, penguasaan kosakata, dan pemahaman tata bahasa.

Koefisien $\mathrm{X}_{1}$ sebesar 0,598 menunjukkan bahwa setiap penambahan 1 skor variabel kemampuan membaca akan menaikkan skor kemampuan menulis narasi sebesar 0,598. Koefisien $\mathrm{X}_{2}$ sebesar 0,600 menunjukkan bahwa setiap penambahan 1 skor variabel penguasaan kosakata akan menaikkan skor kemampuan menulis narasi sebesar 0,600. Koefisien $\mathrm{X}_{1}$ sebesar 0,189 menunjukkan bahwa setiap penambahan 1 skor variabel pemahaman tata bahasa akan menaikkan skor kemampuan menulis narasi sebesar 0,189. Variabel terikat (Y) sebesar 22,826 . Hal ini menjelaskan bahwa apabila seluruh variabel bebas dimaksimalkan, maka akan meningkatkan skor kemampuan menulis narasi siswa sebesar 22,826. Angka positif menunjukkan semakin tinggi skor membaca, kosakata, dan tata bahasa siswa, semakin tinggi pula kemampuan menulis narasi siswa.

Kesimpulan yang bisa ditarik bahwa setiap penambahan dari variabel bebas akan diikuti oleh kenaikan variabel terikat. Nilai regresi yang positif dari kemampuan membaca, penguasaan kosakata, dan pemahaman tata bahasa siswa, menunjukkan bahwa makin tinggi kemampuan membaca, kosakata, dan tata bahasa siswa, hasil menulis siswa pun akan meningkat.

Hasil penelitian ini membuktikan bahwa kemampuan membaca, penguasaan kosakata, dan pemahaman tata bahasa berpengaruh dalam meningkatkan kemampuan menulis narasi siswa. Hal tersebut sesuai dengan teori yang dikemukakan Sirait, et. al. (1985, pp.1-2) bahwa kegiatan menulis memerlukan tiga hal pokok yaitu: ide, kosakata, dan struktur. Browne (2001:107) mengungkapkan bahwa ide-ide yang digunakan dalam tulisan dapat diperoleh dengan membaca. Melalui kegiatan membaca seseorang akan memperoleh banyak hal yang dapat dijadikan sebagai bahan tulisan.

Selanjutnya, untuk menghasilkan tulisan narasi diperlukan sejumlah kata-kata yang kemudian dirangkai menjadi sebuah cerita. Hal ini didukung oleh Swales \& Feak (1994:34) yang mengemukakan bahwa kegiatan menulis memerlukan kosakata dan struktur. Penguasaan kosakata yang banyak akan memudahkan siswa untuk memilih kata-kata yang tepat untuk dirangkai menjadi sebuah cerita. Selain itu, kemahiran dalam menggunakan kaidah bahasa akan membantu siswa dalam menyusun cerita yang baik. 
Hipotesis kedua yaitu "ada pengaruh signifikan kemampuan membaca terhadap kemampuan menulis narasi siswa". Hipotesisi ini dianalisis dengan menggunakan regresi parsial. Hasil analisis regresi parsial dengan uji-t menunjukkan nilai $\mathrm{t}_{\text {hitung }}=4,481$ pada taraf signifikansi 0,000 . Nilai signifikan lebih kecil dari $\alpha=0,05$ $(\mathrm{p}<0,05)$. Dengan demikian, dapat diketahui bahwa kemampuan membaca berpengaruh terhadap kemampuan menulis narasi siswa.

Besarnya pengaruh kemampuan membaca terhadap kemampuan menulis narasi siswa adalah 0,250 atau $25 \%$. Hal ini berarti bahwa $25 \%$ kemampuan menulis narasi siswa diterangkan oleh kemampuan membaca siswa. Rangkuman hasil analisis regresi parsial dapat dilihat pada Tabel 6 berikut.

Tabel 6. Hasil Analisis Regresi Parsial Kemampuan Membaca

\begin{tabular}{llll}
\hline Model & Coefisients beta & $\mathrm{t}$ & Sig. \\
Constant & 29.560 & 17.943 & .000 \\
$\mathrm{X} 1$ & .593 & 4.481 & .000 \\
\hline
\end{tabular}

Persamaan garis regresi pengaruh kemampuan membaca terhadap kemampuan menulis narasi siswa jika penguasaan kosakata dan pemahaman tata bahasa dibuat tetap adalah $\mathrm{v}=$ $29,560+0,593 X_{1}$ Persamaan ini menunjukkan bahwa nilai koefisien $X_{1}$ sebesar 0,593. Hal ini berarti apabila kemampuan membaca siswa bertambah 1 skor, maka kemampuan menulis narasi siswa akan meningkat 0,593.

Berdasarkan hasil penelitian ini dapat diungkap bahwa kegiatan membaca berpengaruh terhadap kegiatan menulis siswa. Temuan ini memperkuat pendapat Browne (2001:107) yang mengatakan bahwa membaca berpengaruh terhadap pembelajaran menulis siswa, karena melalui kegiatan ini siswa akan memperoleh informasi serta ide-ide yang dapat digunakan sebagai bahan tulisan.

Temuan ini juga memperkuat hasil penelitian Tabatabaei \& Ali (2012:381) mengenai pengaruh kegiatan membaca sebelum menulis. Hasil penelitian mereka mengungkapkan bahwa kegiatan membaca sebelum menulis memberi kontribusi besar dalam peningkatan menulis siswa. Menurut mereka, hasil menulis siswa jauh lebih baik jika didahului kegiatan membaca terlebih dahulu sebelum menulis. Melalui kegiatan membaca seseorang akan memperoleh banyak pengetahuan yang dapat dijadikan ideide dalam kegiatan menulis. Dengan demikian, dapat disimpulkan bahwa salah satu langkah untuk mengembangkan kemampuan menulis narasi siswa adalah meningkatkan kemampuan membaca siswa.

Hipotesis ketiga yaitu "ada pengaruh signifikan penguasaan kosakata terhadap kemampuan menulis narasi siswa.Hipotesis ini dianalisis dengan menggunakan regresi parsial. Hasil analisis regresi parsial dengan uji-t menunjukkan nilai $t_{\text {hitung }}$ sebesar 3,022 pada taraf signifikansi 0,003 . Nilai signifikan kurang dari $\alpha 0,05(p<0,05)$. Dengan demikian, dapat diketahui bahwa penguasaan kosakata berpengaruh terhadap kemampuan menulis narasi.

Besarnya pengaruh penguasaan kosakata terhadap kemampuan menulis narasi siswa adalah 0,309 atau 30,9\%. Hal ini berarti bahwa 30,9\% kemampuan menulis narasi siswa diterangkan oleh penguasaan kosakata siswa. Rangkuman hasil analisis regresi parsial dapat dilihat pada Tabel 7 berikut.

Tabel 7. Hasil Analisis Regresi Parsial Penguasaan Kosakata

\begin{tabular}{llll}
\hline Model & Coefisients beta & $\mathrm{t}$ & Sig. \\
Constant & 29.560 & 17.943 & .000 \\
$\mathrm{X} 2$ & .600 & 3.022 & .003 \\
\hline
\end{tabular}

Persamaan garis regresi pengaruh penguasaan kosakata terhadap kemampuan menulis narasi siswa jika kemampuan membaca dan pemahaman tata bahasa dibuat tetap adalah $\mathrm{v}$ $=29,560+0,600 X_{2}$ Persamaan ini menunjukkan bahwa nilai koefisien $\mathrm{X}_{2}$ sebesar 0,600 . Hal ini berarti apabila penguasaan kosakata siswa bertambah 1 skor, maka kemampuan menulis narasi siswa akan meningkat 0,600 .

Hasil penelitian ini menunjukkan bahwa siswa yang memperoleh nilai tes kosakata tinggi terbukti memperoleh nilai menulis narasi yang tinggi. Sebaliknya, siswa yang memperoleh nilai tes kosakata rendah juga memperoleh nilai menulis narasi yang rendah. Hal ini membuktikan bahwa penguasaan kosakata 
berpengaruh dalam meningkatkan kemampuan menulis narasi siswa.

Penguasaan kosakata merupakan dasar dalam peningkatan kemampuan menulis narasi. Penguasaan kosakata yang banyak akan memudahkan siswa dalam mengungkapkan pikirannya. Temuan ini menguatkan pendapat Tarigan (2008:2) yang mengatakan bahwa keterampilan berbahasan seseorang yang meliputi kemampuan menyimak, membaca, berbicara, dan menulis tergantung pada penguasaan kosakata yang dimilikinya. Semakin banyak kosakata yang dimiliki siswa, semakin besar kemungkinan seseorang untuk terampil berbahasa.

Selain itu, penelitian tentang adanya pengaruh penguasaan kosakata dengan kemampuan menulis narasi ternyata dapat menguatkan penelitian- sebelumnya. Hasil penelitian Olinghouse \& Leaird (2009, pp.245-265) menunjukkan bahwa kekayaan kosakata yang dimiliki siswa berpengaruh dalam meningkatkan kemampuan menulis narasi siswa. Selain itu, hasil penelitian Krisnawati (1997) menunjukkan bahwa ada pengaruh kebiasaan membaca dan penguasaan kosakata terhadap kemampuan menulis deskripsi siswa. Kebiasaan membaca memberikan sumbangan sebesar 35,088, dan penguasaan kosakata memberikan sumbangan sebesar 26,146. Dengan demikian, dapat simpulkan bahwa salah satu cara yang dapat dilakukan untuk mengembangkan kemampuan menulis narasi siswa adalah meningkatkan penguasaan kosakata mereka.

Hipotesis ketiga berbunyi "ada pengaruh signifikan pemahaman tata bahasa terhadap kemampuan menulis narasi siswa. Hipotesis ini dianalisis dengan menggunakan regresi parsial. Hasil analisis regresi parsial dengan uji-t menunjukkan nilai $t_{\text {hitung }}$ sebesar 1,113 pada taraf signifikansi 0,267. Berdasarkan hasil tersebut, dapat diketahui bahwa nilai signifikansi lebih besar dari á $0,05(p>0,05)$. Hal ini menunjukkan bahwa hipotesis tidak diterima, artinya tidak ada pengaruh signifikan antara pemahaman tata bahasa terhadap kemampuan menulis narasi jika kemampuan membaca, dan penguasaan kosakata dibuat tetap. Hasil penelitian ini dapat bermakna bahwa hubungan antara pemahaman tata bahasa dan kemampuan menulis narasi tidak dapat berlaku untuk populasi yaitu seluruh siswa SMP Negeri di Kabupaten Bulukumba, tetapi hanya berlaku untuk sampel penelitian. Rangkuman hasil analisis regresi parsial dapat dilihat pada Tabel 8 berikut.

Tabel 8. Hasil Analisis Regresi Parsial Pemahaman Tata Bahasa

\begin{tabular}{llll}
\hline Model & Coefisients beta & $\mathrm{t}$ & Sig. \\
Constant & 29.560 & 17.943 & .000 \\
$\mathrm{X} 1$ & .189 & 1.113 & .267 \\
\hline
\end{tabular}

Penyajian analisis deskriptif menunjukkan bahwa skor tertinggi tes tata bahasa yang diperoleh siswa adalah 14 dari 20 butir soal. Skor yang paling banyak diperoleh siswa adalah 9 dengan jumlah siswa 23. Siswa yang mampu menjawab lebih dari separuh jumlah soal tata bahasa dengan benar 42 orang. Hal ini menunjukkan bahwa hanya sedikit siswa yang mampu menjawab soal dengan benar.

Rendahnya hasil tes tata bahasa yang diperoleh siswa tidak terlepas dari instrumen tes yang digunakan untuk mengukur pemahaman tata bahasa siswa. Setelah diteliti kembali, ternyata diperoleh beberapa butir soal yang tidak tepat. Hal ini menyebabkan data yang diperoleh belum benar-benar mewakili kemampuan siswa. Melalui hasil ini, dapat dipahami bahwa sebenarnya bukan tidak ada pengaruh pemahaman tata bahasa terhadap kemampuan menulis narasi siswa. Akan tetapi, adanya masalah dari segi validitas konstruk instrumen, menyebabkan hasil tes tata bahasa menjadi rendah.

Dalam kaitannya dengan hipotesis yang diuji, dapat ditekankan bahwa pemahaman tata bahasa tidak berpengaruh secara signifikan terhadap kemampuan menulis narasi siswa. Hasil analisis data tidak mendukung teori-teori yang dikemukakan dalam kajian pustaka. Akan tetapi, hasil penelitian ini didukung oleh teori yang dikemukakan oleh Suparno \& Yunus (2007:15) bahwa kaidah penulisan bukan inti dalam kegiatan menulis, melainkan hanya merupakan salah satu alat yang digunakan untuk mengemas tulisan agar dapat dipahami oleh pembaca. Agar dapat menulis dengan baik, seseorang harus banyak berlatih, sebagaimana yang dikemukakan oleh Alwasilah \& Alwasilah (2007:43) bahwa 
kemampuan menulis siswa akan baik kalau melakukan latihan yang intensif.

Selain itu, Pardiyono (2007:iii) mengungkapkan bahwa pada umumnya kesalahan guru dalam pembelajaran menulis adalah menekankan penulisan kalimat secara gramatikal, bukan pada tataran informasi. Akibatnya, siswa hanya dapat menulis rentetan kalimat saja, tetapi tidak dapat mengemas ide menjadi teks yang baik.

Bertolak dari hal tersebut, maka dapat disimpulkan bahwa faktor-faktor yang menjadi penyebab ditolanya hipotesis keempat sebagai berikut. Pertama, tidak ada pengaruh signifikan pemahaman tata bahasa terhadap kemampuan menulis narasi pada siswa SMP Negeri di Kabupaten Bulukumba jika kemampuan membaca dan penguasaan kosakata dikontrol. Kedua, instrumen yang kurang valid menyebabkan data yang diperoleh belum benar-benar mewakili kemampuan siswa. Ketiga, tata bahasa bukanlah hal utama yang harus dikuasai siswa sebelum menulis narasi. Akan tetapi, siswa harus banyak berlatih agar dapat menghasilkan tulisan narasi yang baik.

\section{SIMPULAN}

Berdasarkan hasil analisis data dan pembahasan, dapat ditarik beberapa kesimpulan dari penelitian ini sebagai berikut. Pertama, kemampuan membaca, penguasaan kosakata, dan pemahaman tata bahasa secara bersama-sama berpengaruh terhadap kemampuan menulis narasi siswa. Berdasarkan hasil analisis regresi ganda diperoleh nilai $\mathrm{F}=24,475$ dan nilai signifikansi $=0,000(p<0,05)$. Nilai koefisien determinan $\left(\mathrm{R}^{2}\right)$ adalah 0,315 atau $31,5 \%$.

Kedua, kemampuan membaca berpengaruh terhadap kemampuan menulis narasi siswa jika dikontrol oleh variabel penguasaan kosakata dan pemahaman tata bahasa. Berdasarkan koefisien uji regresi parsial diperoleh nilai $\mathrm{t}_{\text {hitung }}=4,481$ dan nilai signifikansi $=0,000(\mathrm{p}<$ $0,05)$. Hal ini menunjukkan bahwa apabila kemampuan membaca meningkat, maka kemampuan menulis narasi siswa akan meningkat.

Ketiga, penguasaan kosakata berpengaruh terhadap kemampuan menulis narasi siswa jika dikontrol oleh variabel kemampuan mem- baca dan pemahaman tata bahasa. Berdasarkan koefisien uji regresi parsial diperoleh nilai $t_{\text {hitung }}$ $=3,022$ dan nilai signifikansi $0,003(\mathrm{p}<0,05)$. Hal ini menunjukkan bahwa apabila penguasaan kosakata meningkat, maka kemampuan menulis narasi siswa akan meningkat.

Keempat, pemahaman tata bahasa tidak berpengaruh terhadap kemampuan menulis narasi siswa jika dikontrol oleh variabel kemampuan membaca dan penguasaan kosakata. Berdasarkan uji regresi parsial diperoleh nilai $t_{\text {hitung }}$ $=1,113$ dan nilai signifikansi 0,267 $(\mathrm{p}>0,05)$. Hal ini menunjukkan bahwa pemahaman tata bahasa tidak berpengaruh dalam meningkatkan kemampuan menulis narasi siswa.

\section{Ucapan Terima Kasih}

Artikel ini disusun berdasarkan tesis yang telah diujikan dan direvisi. Oleh karena itu, saya mengucapkan terima kasih kepada pembimbing Prof. Dr. Haryadi dan dewan penguji tesis lainnya yang telah memberi masukkan dan saran terhadap tesis saya. Dengan bantuan tersebut artikel hasil penelitian ini dapat diwujudkan.

\section{DAFTAR PUSTAKA}

Alwasilah, A. Chaedar., \& Alwasilah, Senny Susanna. 2007. Pokoknya Menulis. Bandung: PT Kiblat Buku Utama.

Arifin, Zainal. 2012. Penelitian Pendidikan. Bandung: PT Remaja Rosdakarya.

Browne, Ann. 2001. Developing Language and Literacy 3-8(2rd ed.). London: Paul Chapman Publishing.

Heffernan, James A.W., \& Lincoln, John E. 1990. Writing a College Handbook ( $3^{r d}$ ed.). New York: Norton \& Company.

Johnson, Andrew. P. 2008. Teaching Reading and Writing. Lanham: United States of America.

Krisnawati, Erlin. 1997. Pengaruh Kebiasaan Membaca dan Penguasaan Kosakata Terhadap Keterampilan Menulis Deskripsi Siswa Kelas II SMU Negeri di Kecamatan Bantul Yogyakarta. Skripsi, tidak diterbitkan, FPBS IKIP Yogyakarta, Yogyakarta. 
Olinghouse, Natalie G., \& Leaird, Jacqueline T. 2009. The Relationship Between Measures of Vocabulary and Narrative Writing Quality in Second and FourthGrade Students. Reading and Writing, 22(4), 545-565.

Pardiyono. 2007. Pasti Bisa! Teaching GenreBased Writing. Yogyakarta: Andi Offset. Siahaan, Sanggam., \& Shinoda, Kisno. 2008. Generic Text Structure. Yogyakarta: Graha Ilmu.

Sinar, Tengku Silvana. 2008. Teori dan Analisis Wacana: Pendekatan Sistematik Fungsional. Medan: Pustaka Bangsa Press.

Sirait, Bistok., et. al. 1985. Pedoman KarangMengarang. Jakarta: Pusat Pembinaan dan Pengembangan Bahasa Departemen Pendidikan dan Kebudayaan.
Suparno \& Yunus, Mohamad. 2007. Keterampilan Dasar Menulis. Jakarta: Universitas Terbuka.

Swales, John M., \& Feak, Christine B. 1994. Academic Wraiting for Graduate Student. Chicago: The Universiry of Michigan Press.

Tarigan, Henry Guntur. (2008). Menulis Sebagai Suatu Keterampilan Berbahasa. Bandung: Angkasa.

Tabatabaei, Omid \& Ali, Hamed Amin. 2012. The Effect of Reading-Based PreWriting Activities on the Writing Performance in an EFL Setting. Journal of Educational and Social Research, $2(2), 381$.

Zainurrahman. 2011. Menulis Dari Teori Hingga Praktik. Bandung: Alfabeta. 